\title{
Dívida ativa: análise da cobrança administrativa e judicial em Municípios do Rio de Janeiro
}

Marcello Sartore de Oliveira e Waldir Jorge Ladeira dos Santos

\section{Introdução}

A dívida ativa, classificada como receita pública corrente, "Outras Receitas Correntes", possui significativa importância na gestão dos entes públicos. É um instrumento importante para que o poder público atinja sua finalidade, que é a consecução do bem comum.

Conforme Kohama (2006, p.84), "constituem dívida ativa a importância relativa a tributos, multas e créditos da Fazenda Pública, lançados, mas não recebidos no prazo do vencimento, a partir da data de sua inscrição”.

A inscrição em dívida ativa está definida no art. 201 do Código Tributário Nacional (CTN):

Art. 201. Constitui dívida ativa tributária a proveniente de crédito dessa natureza, regularmente inscrita na repartição administrativa competente, depois de esgotado o prazo fixado, para pagamento, pela lei ou por decisão final proferida em processo regular. 
Sendo assim, dívida ativa tributária é a dívida inscrita na repartição competente depois da constituição definitiva, ou seja, depois de esgotado o prazo fixado para pagamento pela lei ou por decisão final proferida em processo regular.

A inscrição em dívida ativa representa, portanto, a consolidação da dívida tributária, daquele débito tributário perante a administração pública, que, pelo menos administrativamente, não mais poderá ser alterado. Essa consolidação é a inscrição em dívida ativa, que pressupõe a inclusão do débito consolidado no cadastro da administração. Esse cadastro da administração é, exatamente, a dívida ativa.

Então, o primeiro requisito para inscrição em dívida ativa é a constituição definitiva do crédito tributário. $\mathrm{O}$ crédito tributário já tem que ser imutável na esfera administrativa. Sendo imutável, pode ser realizada a inscrição em dívida ativa.

Só que a dívida ativa pode ou não ser tributária, conforme preceitua o art. 39 da Lei $n^{2}$ 4.320/64:
Art. 39. Os créditos da Fazenda Pública, de natureza tributária ou não tributária, serão escriturados como receita do exercício em que forem arrecadados, nas respectivas rubricas orçamentárias.

Foram analisadas informações dos balanços orçamentários de oitenta e nove ${ }^{1}$ Prefeituras Municipais do Estado do Rio de Janeiro do ano de 2009 e de noventa ${ }^{2}$ Prefeituras em 2010, num total de noventa e duas, cujos dados referentes a esses exercícios fiscais foram encaminhados, pelas próprias Prefeituras, à STN e por isso constam no FINBRA ${ }^{3}$. A partir dessa análise, percebe-se que a cobrança/recebimento da dívida ativa alcançou, em 2010, R $\$ 498$ milhões, sendo que a dívida ativa tributária atingiu R\$ 419 milhões, ou seja, 84,11\%, enquanto que a não tributária obteve $\mathrm{R} \$ 79$ milhões, $15,89 \%$ do total do recebimento da dívida ativa. Segue gráfico referente à arrecadação da dívida ativa em 2009 e 2010.

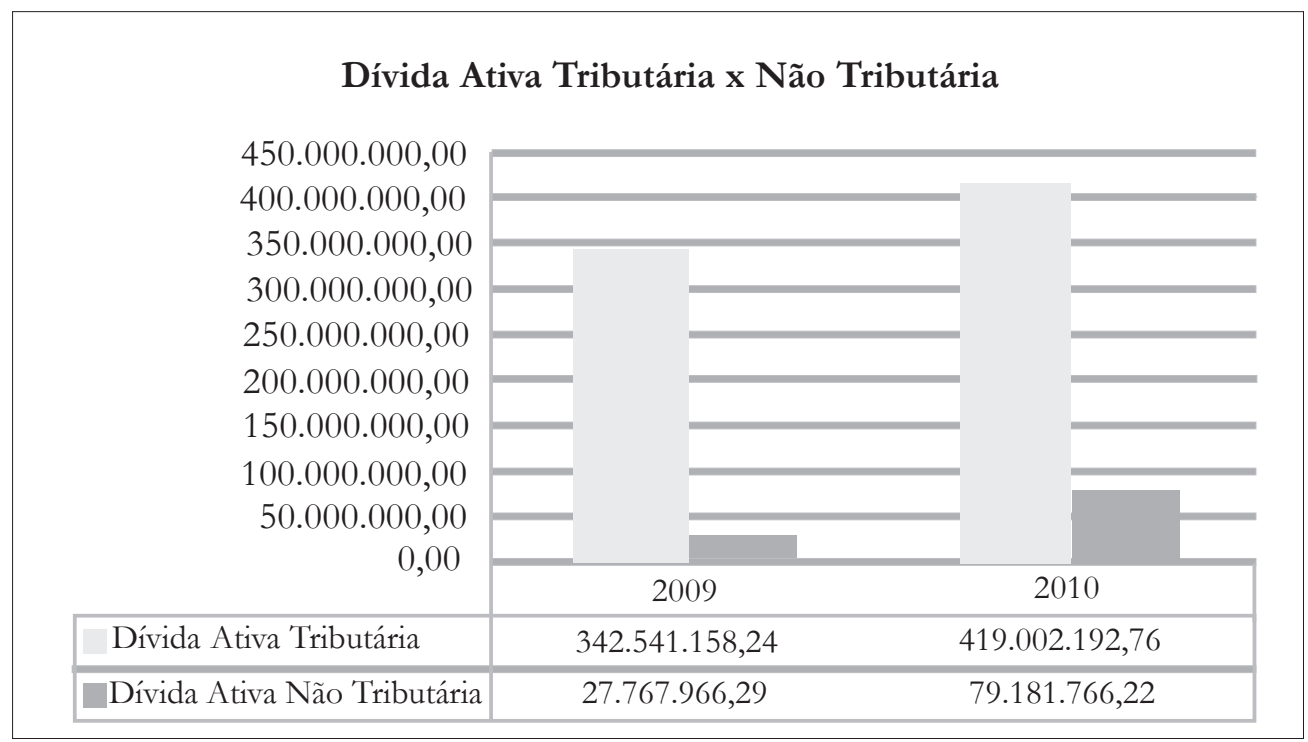

Fonte: Secretaria do Tesouro Nacional - adaptado pelo autor.

Gráfico 1: Comparação entre a receita de dívida ativa tributária e não tributária $\operatorname{anos} 2009$ e 2010 
Em 2009, os valores arrecadados com a dívida ativa chegaram a $R \$ 370$ milhões, com a tributária atingindo $\mathrm{R} \$ 342$ milhões, correspondendo a 92,5\% do total, e a dívida ativa não tributária, com R\$ 27 milhões, alcançando, portanto, apenas 7,5\%.

A dívida ativa é uma fonte de recursos que advém de uma frustração de arrecadação, sendo importante para que o poder público atinja sua finalidade, que é a consecução do bem comum da sociedade. Representa um conjunto de direitos de diversas naturezas, a favor da Fazenda Pública, que não foram pagos pelos devedores nos prazos previstos na legislação vigente.

A não cobrança da dívida ativa, além de implicar o não ingresso de receita pública ao erário, acaba por estimular o surgimento de novos inadimplentes, em decorrência, especialmente, da inércia do poder público, que acaba por gerar a impressão de impunidade.

Evidenciando a necessidade de um estudo mais acurado sobre esse tema, é possível perceber que em $90^{4}$ (noventa) Municípios fluminenses, em 2010, conforme dados do FINBRA $^{5}$, da Secretaria do Tesouro Nacional (STN), o valor referente ao estoque de dívida ativa atingiu a cifra de $\mathrm{R} \$ 34.986 .294 .931,71$, enquanto que a receita tributária, no mesmo período, alcançou o valor de $\mathrm{R} \$$ 8.696.901.660,66. Isso significa que, para esses 90 municípios fluminenses, o estoque de dívida ativa representava 4,02 vezes o valor arrecadado com as receitas tributárias no ano de 2010.

Quanto ao investimento público, que, conforme Ferreira (1996), é peça-chave para garantir o crescimento econômico sustentado da economia e, especialmente, para o fornecimento dos serviços necessários à população, no mesmo período de 2010, os 90 municípios realizaram despesas de investimento $^{6}$ no total de $\mathrm{R} \$ 3.804 .775 .871,83$, perfazendo menos de $10 \%$ de seus estoques da dívida ativa.

Comparando a despesa de investimentos com os créditos a serem recebidos pelos Municípios, verificou-se que o estoque da dívida ativa representou $911,22 \%$ do total dos investimentos municipais, no ano de 2010. Percebe-se, então,

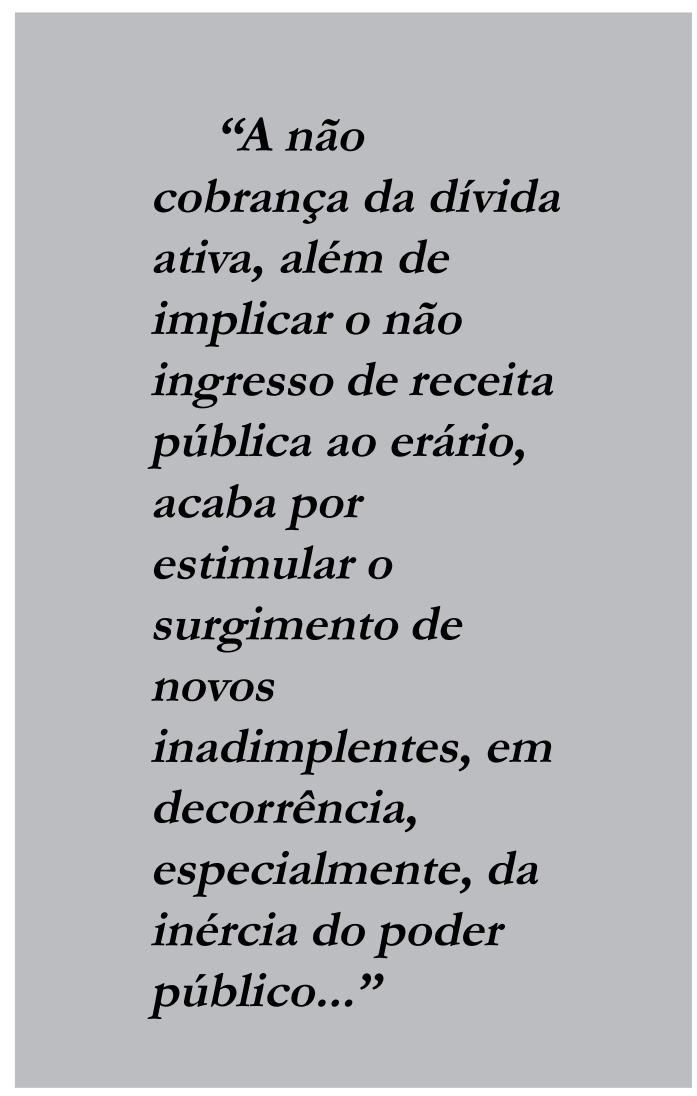

que, se os 90 entes municipais fluminenses, nesse período, tivessem recebido de forma integral os recursos inscritos em dívida ativa e quisessem melhor promover o bemestar da sociedade, poderiam mais do que decuplicar os recursos aplicados em investimentos públicos, o que melhoraria substancialmente a qualidade de vida da sociedade assistida. 
A necessidade de arrecadar mais e de forma eficiente passa a ser a saída para que os entes municipais obtenham mais recursos, para serem aplicados em investimentos nas mais diversas áreas.

Justifica-se a inclusão do Poder Judiciário neste trabalho uma vez que, conforme informação veiculada pelo Conselho Nacional de Justiça (CNJ), a partir da pesquisa "Justiça em Números - 2009", esse Poder também envolve ganhos significativos para o Estado. Naquele período, conforme o CNJ, foram arrecadados pelo judiciário $R$ \$ 19,3 bilhões em receitas, oriundas da cobrança da dívida ativa, para os cofres públicos.

Desse modo, torna-se pertinente, relevante e oportuno incluir o Poder Judiciário no centro da discussão referente ao aperfeiçoamento do controle de gestão sobre a dívida ativa, em virtude de essa instância ter intensa relação, mesmo que atípica, com a arrecadação de recursos públicos para a administração pública brasileira.

Em relação à contribuição acadêmica, esta pesquisa justifica-se pela limitação de obras na literatura brasileira relacionadas à análise da necessidade de cooperação, e de responsabilização, entre os Poderes Judiciário e Executivo Municipal no controle da arrecadação da dívida ativa.

Com este estudo pretende-se fornecer respostas para o seguinte problema de pesquisa: quais os procedimentos que devem ser adotados pelos entes municipais e pelo Poder Judiciário para que seja possível aperfeiçoar o controle de gestão sobre a dívida ativa e, assim, aumentar a arrecadação dessa receita pública, tanto na esfera administrativa como na judicial, e, consequentemente, diminuir a quantidade de ações judiciais de cobrança da dívida ativa?

\section{Modalidades de cobrança da dívida ativa}

A dívida ativa pode ser cobrada tanto na via administrativa, como na judicial. A Lei n. ${ }^{\circ} \quad 6.830 / 80$, que dispõe sobre a cobrança judicial da dívida ativa da Fazenda Pública, acabou por consagrar definitivamente a tendência doutrinária de diferenciar a execução judicial da execução administrativa.

\section{Cobrança Amigável}

$\mathrm{Na}$ cobrança da dívida ativa, a nível administrativo, entende-se que o ente público municipal deve buscar de todas as formas possíveis, sempre autorizadas em lei, a efetivação do recebimento de seu direito.

Existe a compreensão, conforme ensinam Neves e Pinto (2006, p.13), de que o caráter amigável da via administrativa acaba por torná-la mais viável para o ente público, por se apresentar como solução mais econômica e menos morosa.

No entanto, a evidência empírica revela que a experiência brasileira não tem sido satisfatória, o que pode ser explicado por fatos institucionais relacionados diretamente à ausência de estrutura física, material, humana e, especialmente, de vontade política das Prefeituras em desempenharem essa relevante função.

Corrobora esse entendimento o fato de que, atualmente, na Justiça Estadual mais da metade - $56 \%$ - dos processos sejam de execução fiscal, conforme informação ventilada no debate "O Aprimoramento das Ferramentas da Cobrança da Dívida Ativa"7. Ou seja, apesar de ser mais econômica e menos morosa, fatores institucionais, como a notória falta de estrutura de cobrança, apontada por Barroso (2006), relacionados à cobrança amigável têm-na transformado num verdadeiro insucesso, 
acarretando, dessa forma, a necessidade de se recorrer à cobrança jurídica. São tantas as ações administrativas infrutíferas transferidas ao Poder Judiciário, que esse Poder, a nível estadual, já possui mais da metade de seu acervo cartorário composto por ações de cobrança de dívida ativa.

Ainda de acordo com Barroso (2006), a ineficiência da cobrança administrativa vem contribuindo para que o estoque desse ativo aumente ao longo dos anos, fazendo, assim, surgir uma necessidade imperiosa de alterações que viabilizem o enchimento dos cofres públicos com o que já lhes pertence.

Analisando o gráfico 2 comprova-se o constante crescimento do estoque da dívida ativa dos Municípios do Estado do Rio de Janeiro, que enviaram seus dados contábeis dos anos de 2007 a 2010 à STN. Não obstante, percebe-se que o recebimento dessa receita corrente apresenta uma discreta elevação, bem insignificante, em relação ao crescimento do estoque. Enquanto que este, em 2010, atingiu R\$ 34,67 bilhões, o recebimento dessa receita alcançou, no mesmo período, apenas $\mathrm{R} \$ 474,76$ milhões, o equivalente a $1,369 \%$ do estoque.

\section{Cobrança Judicial}

O processo de cobrança da dívida ativa, por meio do Poder Judiciário, também é chamado de Execução Fiscal e tem suas regras regidas pela Lei $\mathrm{n}^{\circ}$ 6.830/80, conhecida como Lei de Execução Fiscal (L.E.F.).

Segundo Borba (2003, p. 538), "a ação de execução fiscal é o processo cabível para que a Fazenda Pública exija coativamente do sujeito passivo aquilo que lhe é devido e não foi pago na época própria". Borba (2003) continua afirmando que essa ação judicial tem como escopo expropriar o contribuinte de seu patrimônio, a fim de que seja satisfeita a pretensão fiscal.

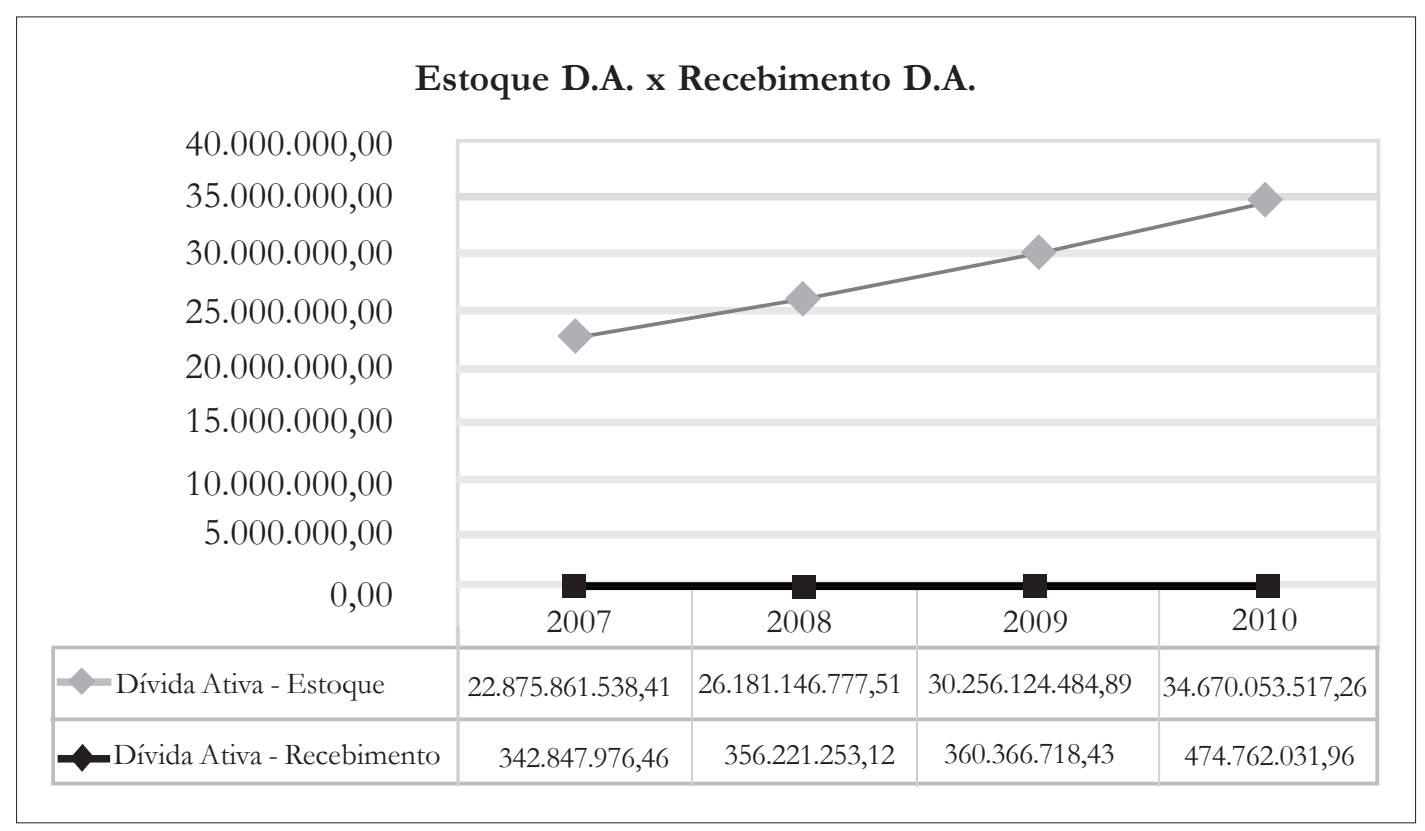

Fonte: Secretaria do Tesouro Nacional - FINBRA - adaptado pelo autor.

Gráfico 2: Comparação entre o estoque da dívida ativa x cobrança da dívida ativa - Municípios do RJ - 2007 a 2010 
É importante salientar que, se o administrador público não fizer o lançamento no prazo legal de cinco anos, geralmente a contar do exercício seguinte àquele em que o lançamento poderia ter sido efetuado, a Fazenda Pública não poderá constituir o crédito tributário, devido à ocorrência da decadência. Por outro lado, se o administrador público, com o débito tributário inscrito em dívida ativa, não realizar a cobrança judicial em novo prazo de cinco anos, a dívida não mais poderá ser cobrada, conforme os artigos 173 e 174 do CTN, o que impõe a necessidade de controle efetivo por parte da Procuradoria do Município ao longo de vários governos, considerando que o mandato é de quatro anos e a decadência, com a prescrição, chega a atingir 10 anos.

\section{Inscrição da dívida ativa e requi- sitos da $\mathrm{CDA}^{8}$}

A inscrição de um crédito tributário em dívida ativa constitui um título executivo extrajudicial chamado de Certidão de Dívida Ativa, que é requisito indispensável para que as respectivas procuradorias judiciais possam regularmente promover a execução judicial da dívida ativa (Almeida, 2012, p. 410).

Realizada a inscrição e esgotadas todas as oportunidades para a quitação administrativa do débito, por meio de cobrança amigável, será proposta ação judicial de cobrança (denominada de ação de execução fiscal), que será instruída com a Certidão de Dívida Ativa (CDA).

A CDA, conforme previsão da Lei $n^{\circ}$ $6.830 / 80$, art. $2^{\circ}$, $\$ 5^{\circ}$, e do CTN, art. 202, deve conter dados obrigatórios sobre o débito, que são: (a) o nome do devedor e, sendo o caso, o dos corresponsáveis, bem como, sempre que possível, o domicílio ou a residência de um e de outros; (b) a quantia devida e a maneira de calcular os juros de mora acrescidos; (c) a origem e natureza do crédito, mencionada especificamente a disposição da lei em que seja fundado; (d) a data em que foi inscrita; (e) sendo o caso, o número do processo administrativo de que se originar o crédito.

Se, após a propositura da ação judicial de cobrança da dívida ativa, constatar-se que a CDA não contém algum dos requisitos elencados acima, não se invalida todo o procedimento executivo, uma vez que a CDA pode ser substituída pelo ente público até a decisão de primeira instância, devolvendo-se ao sujeito passivo, acusado ou interessado, o prazo para defesa, que somente poderá versar sobre a parte modificada. (Lei $n^{\circ} 6.830 / 80$, art. 2º, $\$ 8^{\circ}$; CTN, art. 203)

Barros (2011) enfatiza que para o STJ, entre as modificações dos requisitos da $\mathrm{CDA}$, aquela referente ao sujeito passivo da execução não pode ser corrigida pelo ente público, já que essa modificação não decorre de simples vício, mas de imputação de responsabilidade pela dívida à pessoa diversa.

Pelo ensinamento do autor acima, entre os requisitos da CDA, se o devedor não for de fato o que consta na certidão, não existirá outra possibilidade, a não ser a nulidade da inscrição e do processo de cobrança dela decorrente.

Tristão (2003) enfatiza que a atualização periódica dos cadastros imobiliários municipais produz informações seguras que tornam possível o cálculo exato do valor da dívida, bem como a comunicação com o devedor. Cadastros imobiliários desatualizados são os responsáveis diretos pelos elevados índices de inadimplência referente ao Imposto Predial e Territorial Urbano (IPTU). 


\section{Garantias da cobrança judicial da dívida ativa}

As garantias existentes na cobrança judicial da dívida ativa são uma forma de se tentar incrementar o recebimento dos créditos públicos em atraso, diminuindo, dessa maneira, o estoque dessa receita corrente, o que pode ser realizado por meio do patrimônio do sujeito passivo, por intermédio da penhora on-line e pela inscrição dos devedores da dívida ativa em cartórios de protestos de títulos.

$\mathrm{O}$ artigo 184 do CTN estabelece que a totalidade dos bens e das rendas, de qualquer origem ou natureza, do sujeito passivo, seu espólio ou sua massa falida, inclusive os gravados por ônus real ou cláusula de inalienabilidade ou impenhorabilidade, seja qual for a data da constituição do ônus ou da cláusula, respondem pelo pagamento do crédito tributário. No entanto, o mesmo artigo aponta como exceção a essa regra os bens e rendas que a lei declare absolutamente impenhoráveis.

Nessa esteira, é importante destacar a Lei no 8.009/90, conhecida como "Bem de Família”, que dispõe que não se penhora o imóvel residencial próprio do casal ou da família, sendo que esse imóvel, geralmente, não responderá por qualquer tipo de dívida civil, comercial, fiscal, previdenciária ou de outra natureza, contraída pelos cônjuges, ou pelos pais, ou filhos que sejam seus proprietários e nele residam.

Todavia, a própria Lei $\mathrm{n}^{2}$ 8.009/90 exclui da impenhorabilidade os créditos de trabalhadores da própria residência e as respectivas contribuições previdenciárias decorrentes do contrato de trabalho, bem como a cobrança de impostos, predial ou territorial, taxas e contribuições devidas em função do imóvel familiar.
Portanto, o contribuinte devedor de IPTU não se encontra amparado pela Lei de "Bem de Família", podendo, dessa maneira, ter seu imóvel penhorado para garantir dívidas junto ao ente municipal, oriundas de seu imóvel, mesmo que familiar.

Outra garantia que o poder público possui na cobrança judicial da dívida ativa, sendo uma novidade decorrente da Lei

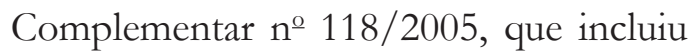
o art. 185-A no CTN, é a penhora on-line.

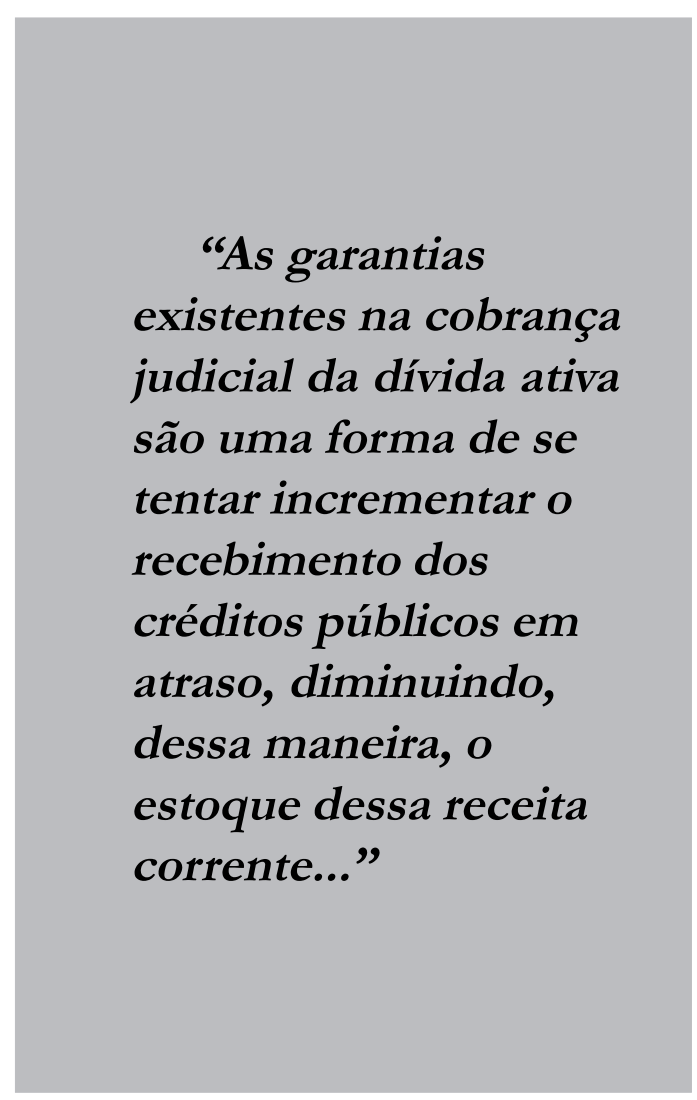

Almeida (2012) afirma que o bloqueio de bens efetivado junto às instituições financeiras é realizado conforme o Bacen-JUD, acordo celebrado entre o Banco Central do Brasil e o Poder Judiciário, que prevê que magistrados podem determinar a imediata indisponibilidade de bens e valores do executado, por meio da internet. 
Quanto à inscrição dos devedores da dívida ativa em cartórios de protestos, a Procuradoria Geral da Fazenda Nacional, por meio da Portaria no 321/2006, estabeleceu que as certidões de dívida ativa da União poderão ser levadas a protesto, antes do ajuizamento da ação de execução fiscal.

No âmbito do Estado do Rio de Janeiro, a Lei $\mathrm{n}^{\mathrm{o}} 5.351 / 2008$ permite que a Procuradoria envie os nomes de devedores inscritos em dívida ativa aos cartórios de protestos.

\section{Ação de improbidade adminis- trativa}

A ação de improbidade administrativa, que estabelece o procedimento de apuração e punição de agentes públicos pela prática de atos de improbidade, visa a que o Judiciário reconheça condutas de improbidade na administração pública, praticadas por administradores públicos, ou por terceiros, e à consequente aplicação das penalidades, com o intuito de se resguardar o princípio da moralidade administrativa.

Para Carvalho Filho (2010), o princípio da moralidade administrativa confere aos agentes públicos a obrigatoriedade de que pratiquem atos que estejam em consonância com a lealdade e a boafé, não restando dúvidas de que a ação de improbidade administrativa é uma importante ferramenta de controle judicial ${ }^{9}$ sobre atos que a lei caracteriza como de improbidade.

Para que um ato de improbidade administrativa fique caracterizado, se faz necessária a presença dos seguintes elementos: sujeito passivo, sujeito ativo e a ocorrência de um dos atos danosos previstos na Lei $\mathrm{n}^{\circ}$ 8.429/92. Os atos de improbidade administrativa são divididos em três modalidades, acarretando diferentes sanções:
- os que acarretam enriquecimento ilícito, previstos no artigo 9;

- os que causam prejuízos ao erário, conforme artigo 10; ; e

- aqueles que atentam contra os princípios da administração pública, previstos no artigo 11 .

Conforme Di Pietro (2006), na modalidade "Dos Atos de Improbidade Administrativa que Causam Prejuízo ao Erário", artigo 10, da Lei n 8.429/92, caput, e seus treze incisos meramente exemplificativos, o agente público responde também na forma culposa, quando pratica a ação de forma imprudente, negligente ou imperita.

Em relação aos sujeitos passivos, conforme debates ocorridos em seminário ${ }^{10} \mathrm{da}$ Escola de Magistratura do Estado do Rio de Janeiro (Emerj), Prefeitos e Secretários Municipais, mesmo sendo enquadrados no conceito de agente político, podem ser responsabilizados por improbidade administrativa, já que a CF/88 não faz alusão a crimes de responsabilidade que possam cometer.

Desse modo, Prefeitos e Secretários Municipais que, mesmo não tendo a intenção de causar prejuízo ao erário, concedam benefício fiscal sem a observância das formalidades legais, bem como ajam de forma negligente na arrecadação de tributos ou rendas, especialmente na gestão da dívida ativa, causando prejuízo ao Estado, ficarão sujeitos à responsabilização por improbidade administrativa (condenação criminal, bem como na esfera cível), independentemente de serem considerados ou não, doutrinariamente, agentes políticos.

Apesar da existência dessa lei há mais de duas décadas, conforme pesquisa realizada no Tribunal de Justiça do Estado do Rio de Janeiro (TJ/RJ) e Ministério Público do Estado do Rio de Janeiro (MPE/RJ), não foi possível identificar algum gestor 
público municipal respondendo, ou que já tenha respondido, pela má administração da dívida ativa. No seminário ocorrido na Emerj especialistas relataram que ainda é um desafio fazer essa lei produzir os efeitos que a sociedade requer.

\section{Controle na administração pública brasileira}

Em um país com dimensões continentais como o Brasil, formado por $5.565^{11}$ Municípios, 26 Estados e pelo Distrito Federal, o controle eficiente e eficaz, não apenas sobre os gastos públicos, como também sobre a arrecadação das receitas públicas, é condição imprescindível para que ocorra seu desenvolvimento de forma constante e segura.

Carvalho Filho (2010, p. 1021) conceitua controle da administração pública como "o conjunto de mecanismos jurídicos e administrativos por meio dos quais se exerce o poder de fiscalização e de revisão da atividade administrativa em qualquer das esferas de Poder".

Em relação à administração pública brasileira, existem órgãos criados com a finalidade de exercer a função de controle, como os Tribunais de Contas Estaduais, Municipais, esses no caso da cidade do Rio de Janeiro e de São Paulo, o Tribunal de Contas da União (TCU), a Controladoria Geral da União (CGU), entre outros. Esses órgãos possuem como característica marcante o fato de estarem voltados, especialmente, para o controle das despesas públicas.

Alexandrino e Vicente (2010) enfatizam que, devido à necessidade de ser exercido controle eficaz de quaisquer órgãos administrativos, o legislador federal, por meio da Emenda Constitucional $n^{2}$ $45 / 2004$, introduziu no texto constitucional a previsão de criação do Conselho
Nacional de Justiça (CNJ) (art. 103-B), órgão com atribuição específica de controle, ao qual compete controlar a atuação administrativa e financeira do Poder Judiciário e o cumprimento dos deveres funcionais dos Juízes.

\section{Meta 3 do Conselho Nacional de Justiça \\ Conforme informação veiculada no} site do Conselho Nacional de Justiça ${ }^{12}$, esse órgão definiu, juntamente com os noventa e um tribunais do País, uma meta prioritária considerada a mais ousada de 2010 para o Poder Judiciário, que consiste na redução em pelo menos $10 \%$ do acervo de processos na fase de cumprimento ou de execução e, em $20 \%$, do acervo de processos de execuções fiscais ${ }^{13}$. A medida está prevista na chamada "Meta 3", que pode contribuir para a solução de um dos maiores gargalos da justiça brasileira; o julgamento de 25 milhões de processos de execução fiscal que atualmente tramitam nos órgãos judiciais do País.

A "Meta 3" tem, portanto, por principal objetivo a redução do acervo de cobrança da dívida ativa, que em 2010 chegou a um total aproximado que corresponde à metade $^{14}$ da quantidade total de demandas judiciais. A referência estabelecida para a "Meta 3" é o estoque de processos ajuizados até 31 de dezembro do ano de 2009, ano em que três milhões de ações de execução fiscal foram ajuizadas e a mesma quantidade solucionada.

A iniciativa do CNJ, por meio da "Meta 3", representa uma inovação no controle de gestão dos processos de execução fiscal, uma vez que nenhum outro órgão tomara alguma medida similar, voltada para o controle da dívida ativa.

Contudo, percebe-se que a decisão do CNJ está relacionada à redução de 
processos de execução fiscal que, conforme apontado pelo IPEA (2011) ${ }^{15}$, possuem um custo médio no valor de $\mathrm{R} \$ 4.368$, o que torna razoável afirmar que a "Meta 3" está diretamente voltada ao controle do gasto público, dado que não estabelece meta para o aumento da arrecadação.

Vale ainda destacar que no mesmo estudo, o IPEA apontou que a morosidade do Poder Judiciário não resulta significativamente do cumprimento de prazos legais, do sistema recursal ou das garantias de defesa do executado. Tampouco resulta do grau de complexidade das atividades administrativas requeridas. Fundamentalmente, é a cultura organizacional burocrática e formalista, associada a um modelo de gerenciamento processual ultrapassado, que torna o executivo fiscal um procedimento moroso e propenso à prescrição.
Não obstante, mesmo a "Meta 3" não estando focada na ampliação da arrecadação, mas tão somente na diminuição do número de processos, analisando os relatórios "Justiça em Números" do CNJ, nota-se que em 2009 a arrecadação do TJ/RJ, oriunda de execução fiscal, atingiu $\mathrm{R}$ \$325.218.455. Em 2010, no primeiro ano após a implantação do "Meta 3", houve um incremento de $14,90 \%$ na arrecadação, pulando para $\mathrm{R} \$$ 373.675.825. E, em 2011, o aumento da arrecadação foi mais significativo, atingindo $50,36 \%$ em relação a 2009 , quando alcançou o montante de R \$ 489.007.427.

Percebe-se, então, que, mesmo a "Meta 3" não estando diretamente voltada ao incremento da arrecadação de receitas públicas, os esforços empreendidos pelo Tribunal fluminense, com o intuito de atender ao $\mathrm{CNJ}$, já repercutem de forma positiva para a sociedade, eis que a

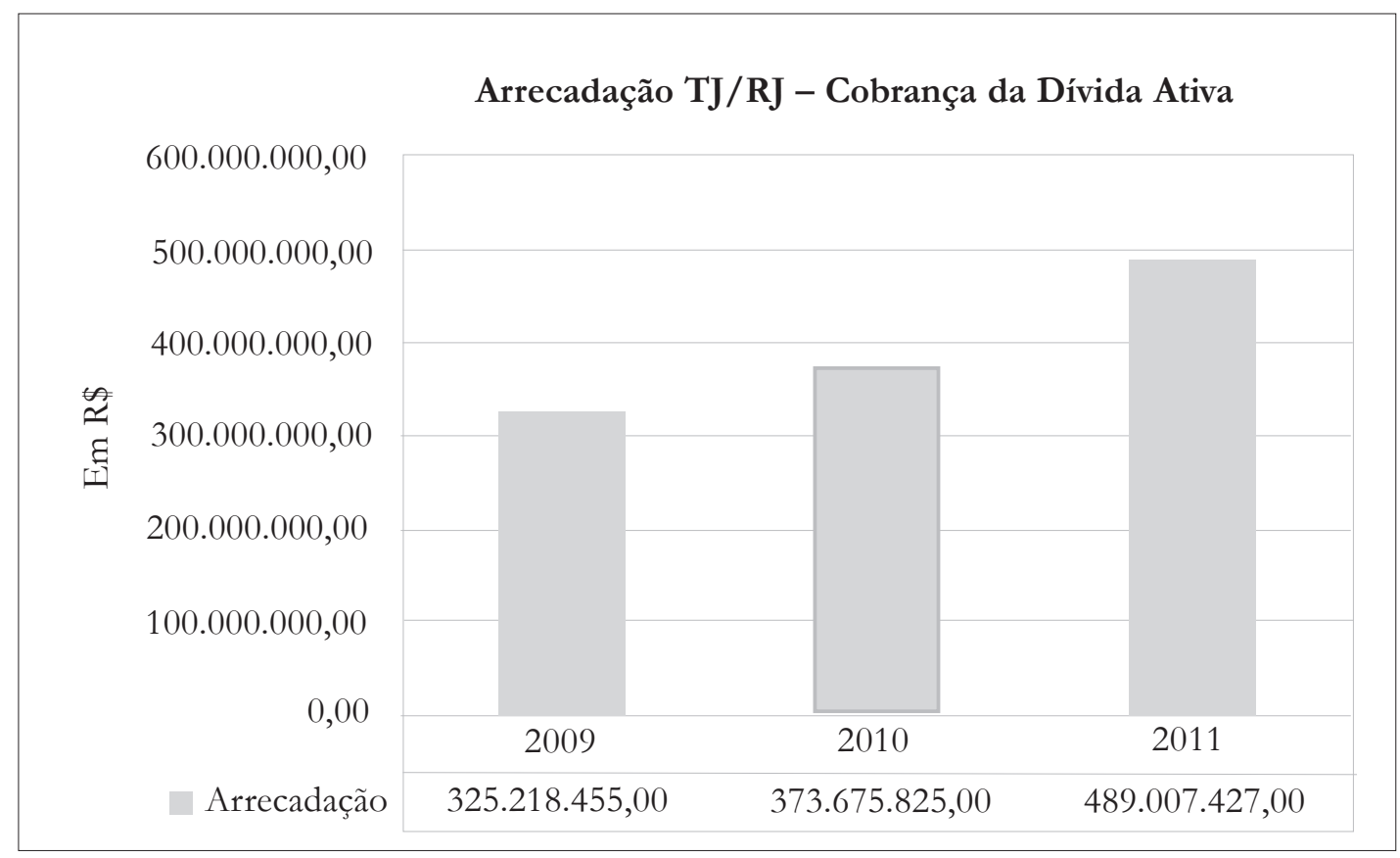

Fonte: $\mathrm{CNJ}$ - adaptado pelo autor.

Gráfico 3: Arrecadação oriunda da Dívida Ativa do TJRJ após a implantação do Meta 3 
arrecadação oriunda da dívida ativa no Rio de Janeiro vem alcançando aumentos significativos desde a implantação da "Meta 3", em 2010.

\section{Metodologia}

Como procedimentos técnicos que nortearam este estudo, foram adotadas as pesquisas bibliográfica, documental e de campo. A condução deste trabalho foi realizada em duas etapas. Na primeira etapa, a pesquisa foi desenvolvida com as fontes impressas, sendo utilizado como instrumento de coleta de dados a pesquisa bibliográfica e a pesquisa documental.

\section{Coleta de dados}

$\mathrm{Na}$ segunda etapa deste trabalho, procedeu-se à pesquisa de campo, quando foi realizado estudo junto a pessoas relacionadas ao objeto da pesquisa, tendo participado seis Procuradores Municipais, sete empresas privadas cobradoras de crédito, 54 servidores do Poder Judiciário que atuam diretamente com a cobrança da dívida ativa, 155 contribuintes que se encontram em débito com a Fazenda Pública. Assim, foram coletados dados que possibilitassem responder ao problema da presente pesquisa.

Foram disponibilizados 500 questionários, com a intenção de analisar o comportamento de contribuintes que se encontram, ou já se encontraram, em débito com a Fazenda Pública. No total foram respondidos 155 questionários, sendo 36 por email, englobando as cidades do Rio de Janeiro, Volta Redonda e Bom Jesus de Itabapoana, e 119 respondidos diretamente pelos contribuintes das cidades de Nova Iguaçu, Parati, Saquarema, Seropédica, Rio Claro e Mangaratiba, todas do Estado do Rio de Janeiro.

Quanto ao Poder Judiciário, a pesquisa foi realizada com os Oficiais de Justiça
Avaliadores que atuam na cobrança da dívida ativa, uma vez que exercem suas atividades por meio do cumprimento de mandados judiciais, atuando, dessa manei$\mathrm{ra}$, de forma direta com os contribuintes que se encontram em débito com a Fazenda Pública. Desse modo, por estarem em contato estreito com os devedores fiscais, esses profissionais foram imprescindíveis para este estudo, no qual se procurou analisar o porquê de a inadimplência sobre as receitas públicas atingir patamares significativos, e o recebimento dessas receitas em atraso atingirem valores quase que inexpressivos.

Dando continuidade ao trabalho de campo, utilizando ainda questionários, procurou-se estimar as estruturas disponibilizadas pelas Prefeituras fluminenses, focando o desempenho desses entes públicos na arrecadação da dívida ativa.

Dessa maneira, procurando atender aos objetivos da presente pesquisa, foram encaminhados aos Procuradores Municipais de 70 Prefeituras Municipais do Estado do Rio de Janeiro questionários com cartas de apresentação nas quais constava que não seriam identificadas as Prefeituras envolvidas- sendo sete entregues de forma direta, e os demais por intermédio de endereços eletrônicos (emails) conseguidos por meio dos sites das Prefeituras. Seis entes municipais chegaram a respondê-los.

Em relação à aferição do desempenho dos Municípios fluminenses, procurou-se realizar comparação com a iniciativa privada. Para isso, buscou-se mensurar, utilizando como amostra quatro entes municipais, a porcentagem de recuperação de valores em atraso, o tempo médio em que esses entes privados iniciam o processo de cobrança, ainda na forma administrativa, bem como o tempo médio em que ingressam na esfera jurídica. 
A população escolhida, quanto à iniciativa privada, refere-se às sociedades de crédito, financiamento e investimento constantes na Divisão de Sistemas Cadastrais (Desic), do Departamento de Monitoramento do Sistema Financeiro (Desig), pertencente ao Banco Central do Brasil (Bacen), conforme veiculado no site deste órgão.

Na lista do Desig constam 405 sociedades corretoras e distribuidoras de títulos e valores mobiliários, corretoras de crédito, financiamento e investimento, de câmbio, agências de fomento, entre outras. Entretanto, desse total, como o objetivo da pesquisa foi analisar o comportamento das sociedades de crédito, financiamento e investimento, a população ficou limitada a 75 empresas.

O questionário foi encaminhado para toda a população selecionada, via correio eletrônico, aos endereços constantes na lista do Desig. A mensagem eletrônica seguiu acompanhada de uma carta de apresentação produzida para esse fim. Foi utilizado aplicativo eletrônico de dados, denominado Googledocs, que não permite a identificação individual dos respondentes, para organizar as respostas do questionário. Para esta pesquisa, sete empresas responderam os questionários.

Quanto ao setor público, a pesquisa ocorreu em quatro Municípios (Seropédica, Paracambi, Paraty e Rio Claro), onde se analisaram inscrições da dívida ativa de Prefeituras Municipais. Foram selecionadas, de forma aleatória, 95 certidões desses Municípios, já em fase de cobrança judicial.

\section{Análise de dados}

Esta seção analisa os resultados das pesquisas que foram realizadas com Procuradores Municipais, empresas privadas cobradoras de crédito, servidores do Poder Judiciário que atuam diretamente com a cobrança da dívida ativa, e contribuintes que se encontram em débito com a Fazenda Pública.

\section{Comparação do desempenho dos entes públicos com a iniciativa privada}

Com a intenção de analisar o desempenho dos entes públicos municipais fluminenses, quanto à cobrança que realizam para reaver seus créditos que indevida e temporariamente se encontram nas mãos dos contribuintes inadimplentes, procurou-se comparar - utilizando como amostra quatro Prefeituras Municipais - a porcentagem de recuperação de valores em atraso, o tempo médio em que esses entes iniciam o processo de cobrança, ainda na forma administrativa, bem como o tempo médio em que ingressam na esfera jurídica, relacionando-os aos das entidades da iniciativa privada.

Quanto ao problema levantado em relação à inadimplência, em relação ao qual se questionou a porcentagem média de recuperação de valores em atraso que as sociedades de crédito, financiamento e investimento consegue alcançar, cabe observar o Gráfico 4.

Pode-se perceber que quatro sociedades privadas, das sete respondentes, relataram que conseguem recuperar acima de $30 \%$ dos valores em atraso. Outras duas responderam recuperar de $10 \%$ a $30 \%$, e, outra, de 3\% a 5\%.

Quanto aos entes públicos municipais do Estado do Rio de Janeiro, conforme Gráfico 2, percebe-se que recuperaram, de 2007 a 2010, em média, 1,369\% do total do que poderia ser arrecadado.

A segunda pergunta procurou mensurar qual o tempo médio que a empresa utiliza para iniciar o processo de cobrança, ainda na esfera administrativa, conforme se observa no Gráfico 5. 
Ao detectarem que um cliente, pessoa física ou jurídica, deixou de honrar um compromisso financeiro, como no atraso no pagamento de uma prestação, o tempo médio que as sociedades afirmaram utilizar, para iniciar o processo de cobrança de seus créditos, ainda na esfera administrativa, não ultrapassa o prazo de 20 dias.

A terceira pergunta encaminhada às sociedades procurou analisar o tempo médio para o ingresso da cobrança na esfera judicial, após não lograrem êxito algum com a cobrança administrativa. As empresas apresentaram as seguintes respostas.

Caso o cliente não honre sua obrigação, mesmo após ser procurado administrativamente pelas sociedades de crédito, financiamento e investimento, o tempo médio para essas empresas transferirem o processo de cobrança para a esfera jurídica, variou de 1 a 6 meses. Cabe ressaltar que a data inicial é o início da inadimplência, e não o término da cobrança administrativa.

Já em relação aos dados obtidos por meio de pesquisa realizada nas Prefeituras Municipais de Rio Claro, Seropédica, Paracambi e Paraty, na qual foram analisadas inscrições em dívida ativa, pode-se extrair as seguintes informações.

Município de Paraty - entre as 25 inscrições de dívida ativa, dos anos de 1993 a 2003, que deram origem a processos judiciais distribuídos entre 1999 a 2008, podese concluir que o tempo médio para inscrever o contribuinte devedor foi de 653,36 dias. Já o tempo médio que a Prefeitura Municipal utilizou para iniciar a cobrança por meio do Poder Judiciário foi de 2047,40 dias, ou seja, 5,6 anos para iniciar a cobrança judicial, após o vencimento da dívida.

Município de Rio Claro - entre as 25 inscrições em dívida ativa, dos anos de 2004 a 2006, que originaram processos judiciais no ano de 2011, a média de tempo para inscrever o inadimplente foi de 255,76 dias, e o tempo médio em que a Prefeitura Municipal utilizou para iniciar a cobrança judiciária foi de 2486,48 dias, ou 6,81 anos.

Município de Paracambi - em vinte inscrições em dívida ativa, dos anos de 2002 a 2009 , que originaram processos judiciais distribuídos entre os anos de 2006 a 2010,

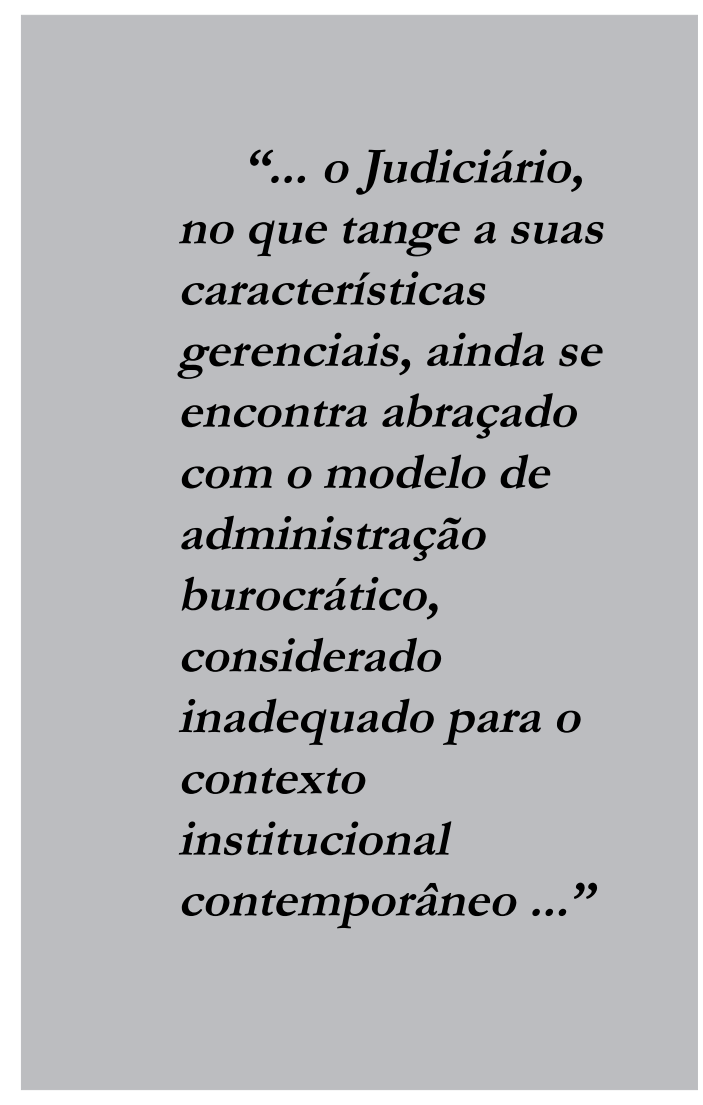

o tempo médio para inscrever o contribuinte devedor foi de 161,45 dias, enquanto que o tempo médio que a Prefeitura Municipal utilizou para iniciar a cobrança judiciária foi de 1333,65 dias, ou melhor, 3,65 anos.

Município de Seropédica - vinte e cinco inscrições em dívida ativa, dos anos de 2007 a 2011, indicaram que a Prefeitura Municipal utilizou o tempo médio, para a inscrição administrativa, de 381,56 dias e, para ingressar na esfera judicial, de 1150,12 dias, portanto 3,15 anos. 


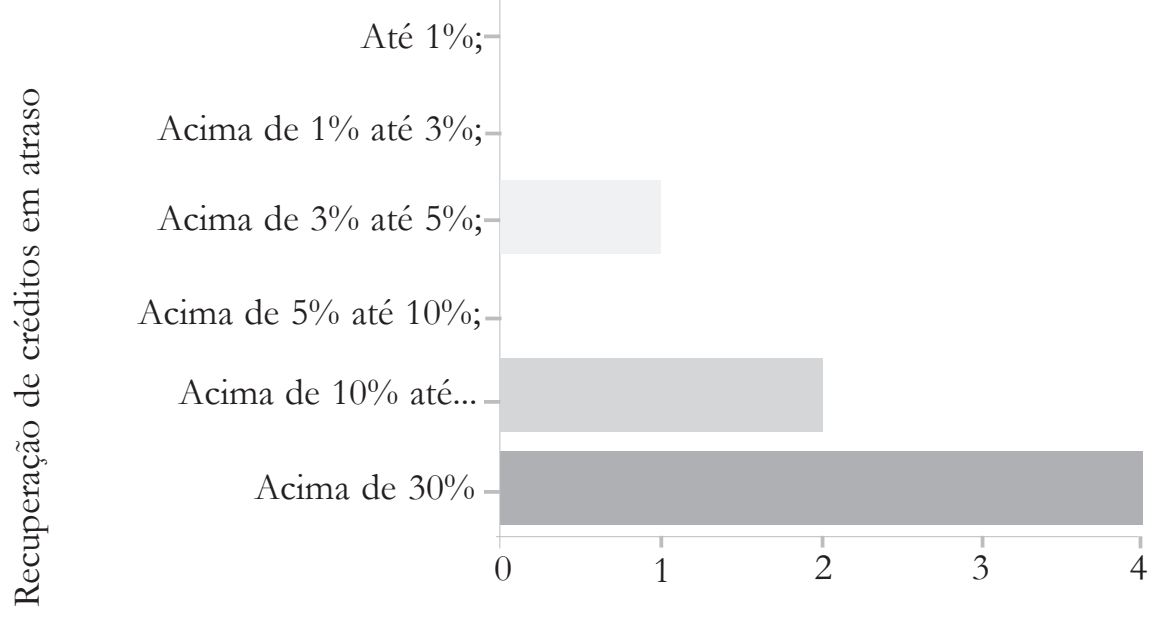

Sociedades Privadas

Fonte: Desig - adaptado pelo autor.

Gráfico 4: Porcentagem de recuperação de créditos em atraso

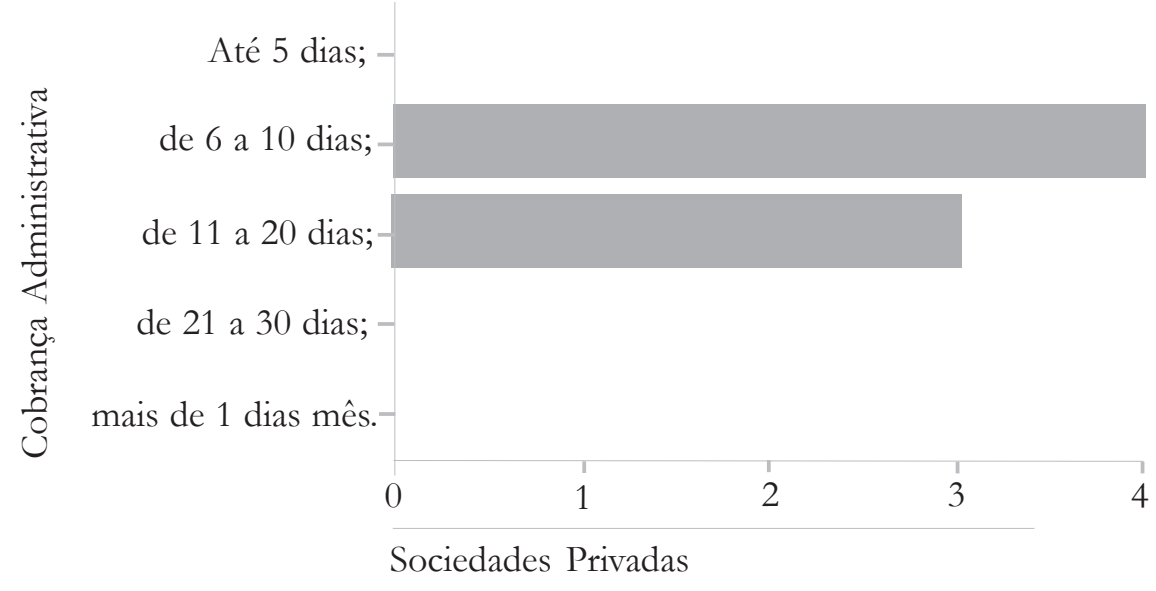

Fonte: Desig - adaptado pelo autor.

Gráfico 5: Tempo médio para início da cobrança administrativa 


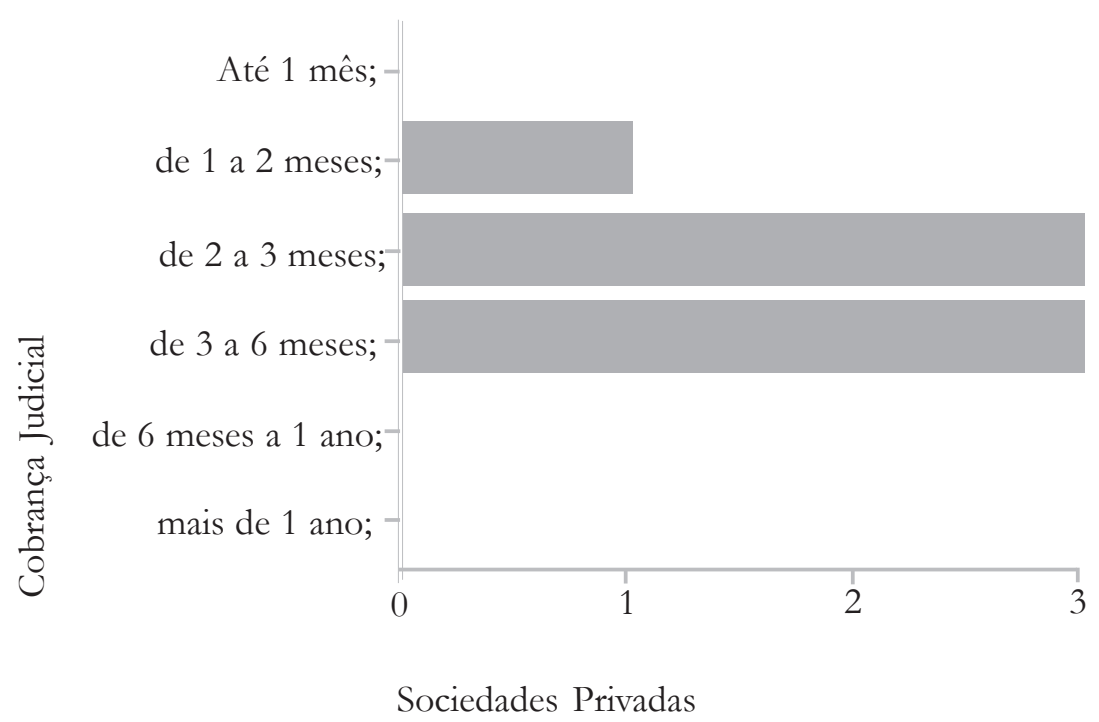

Fonte: Desig - adaptado pelo autor.

\section{Gráfico 6: Tempo médio para início da cobrança Judicial}

Fazendo comparação entre as Prefeituras Municipais analisadas com as sociedades de crédito, financiamento e investimento, pode-se observar a Tabela 1.

Preferiu-se utilizar a média de recuperação de créditos a receber de todas as Prefeituras Municipais do Estado do Rio de Janeiro que encaminharam seus dados à STN, uma vez que a Prefeitura de Paracambi, onde também se analisaram as certidões de dívida ativa, informou que no ano de 2007 não havia qualquer valor a receber em seu balanço patrimonial.

Cabe ressaltar que nas sociedades de crédito, financiamento e investimento, a maior parte dos respondentes relataram recuperar acima de 30\% dos créditos em atraso, enquanto que as Prefeituras fluminenses recuperaram, entre 2007 e 2010, a média irrisória de 1,369\%.

Em relação ao tempo médio para iniciar a cobrança a nível administrativo, as organizações do setor privado responderam que, no máximo, levam 20 dias para iniciar esse procedimento. As do setor público municipal, para inscrever em dívida ativa, levam em média 653,56 dias, portanto, quase dois anos. Quanto à última pergunta da pesquisa, essas utilizaram o prazo de quase cinco anos para ingressar na esfera jurídica, enquanto que as do setor privado, menos de seis meses.

Observação que merece ser destacada é quanto ao prazo para iniciar a cobrança a nível jurídico, que, conforme respostas, as Prefeituras Municipais informaram levar quase cinco anos. Este prazo, cinco anos, é o tempo limite, estabelecido na legislação, para não ocorrer a prescrição referente a essas cobranças. Ou seja, em que pese esse longínquo prazo, que muito prejudica o desempenho da arrecadação (pois quanto mais tempo leva para iniciar a cobrança, menores são as chances de se localizar o devedor, em decorrência de mudança de endereço, falência, falecimento etc), os entes municipais estão praticando atos amparados pela legislação em vigor.

Por fim, é importante ressaltar, há um possível argumento que justifique essa 
Tabela 1: Prefeituras Municipais x sociedades de crédito

\begin{tabular}{c|c|c|c}
\hline & $\begin{array}{c}\text { Porcentagem de } \\
\text { recuperação }\end{array}$ & $\begin{array}{c}\text { Tempo médio para } \\
\text { iniciar cobrança } \\
\text { administrativa }\end{array}$ & $\begin{array}{c}\text { Tempo médio para } \\
\text { ingressar na esfera } \\
\text { judicial }\end{array}$ \\
\hline $\begin{array}{c}\text { Prefeituras } \\
\text { Municipais }\end{array}$ & $1,369 \%^{1}$ & 363,03 dias $^{2}$ & 1754,41 dias \\
\hline SCFI & Acima de $30 \%{ }^{3}$ & até 20 dias & De 30 a 180 dias \\
\hline
\end{tabular}

Fonte: Desig e Prefeituras Municipais analisadas, 2013 - adaptado pelo autor.

${ }^{1}$ Média de recebimento dos anos de 2007 a 2010, conforme Gráfico 2.

${ }^{2}$ Tempo médio para inscrever em dívida ativa entre as 4 Prefeituras.

${ }^{3}$ Resposta apresentada pela maioria dos respondentes.

diferença exacerbada na atenção dispensada pelas Prefeituras Municipais quanto ao tratamento da cobrança de valores a receber, em comparação com as sociedades de crédito, financiamento e investimento, que evidencia a diminuta atenção dos entes públicos municipais analisados, em relação à cobrança da dívida ativa. Trata-se da ausência de leis mais rígidas, que contribuam para um maior controle sobre a gestão da receita pública e que possuam, entre outros requisitos, menores prazos para que esses entes se manifestem nas atividades de cobrança, inclusive com penas que sejam aplicadas, para que obriguem gestores públicos a exercerem suas atividades como se estivessem na iniciativa privada.

\section{Pesquisa realizada junto à sociedade}

Por meio dos 155 questionários respondidos, do total de 500 impressos, nos quais se tentou saber como, na vida dos contribuintes que se encontram ou já se encontraram em débito com a Fazenda Pública, a execução fiscal tem funcionado, e os motivos que os levam a atrasar ou a não pagar as cobranças tributárias e não tributárias muni- cipais. A presente pesquisa apontou, como aspectos mais importantes, os seguintes.

Quanto aos motivos que os contribuintes acreditam que ocasionaram atrasos, ou mesmo o não pagamento, das obrigações junto às Prefeituras, como o IPTU, os que apresentaram maiores evidências foram a ausência de melhoria na cidade, seguido pelo fato de a cobrança do IPTU não vir no nome do atual responsável pelo imóvel, e a necessidade dos contribuintes de pagar despesas pessoais e não sobrar recurso para pagamento de tributos.

Sendo os motivos do atraso, ou da inadimplência, a ausência de melhoria na cidade, os contribuintes apontaram como as mais necessárias em seus bairros: saúde, saneamento básico e pavimentação asfáltica.

$\mathrm{O}$ aspecto mais importante observado nas respostas dos contribuintes foi o fato de afirmarem que em nenhum momento foram procurados por algum servidor $\mathrm{da}$ Prefeitura Municipal em seus endereços, com o intuito de orientá-los sobre como resolver dívidas com esse ente político. Portanto, dos 155 contribuintes, todos afirmaram nunca terem recebido alguma visita da Prefeitura para resolver a pendência fiscal. 


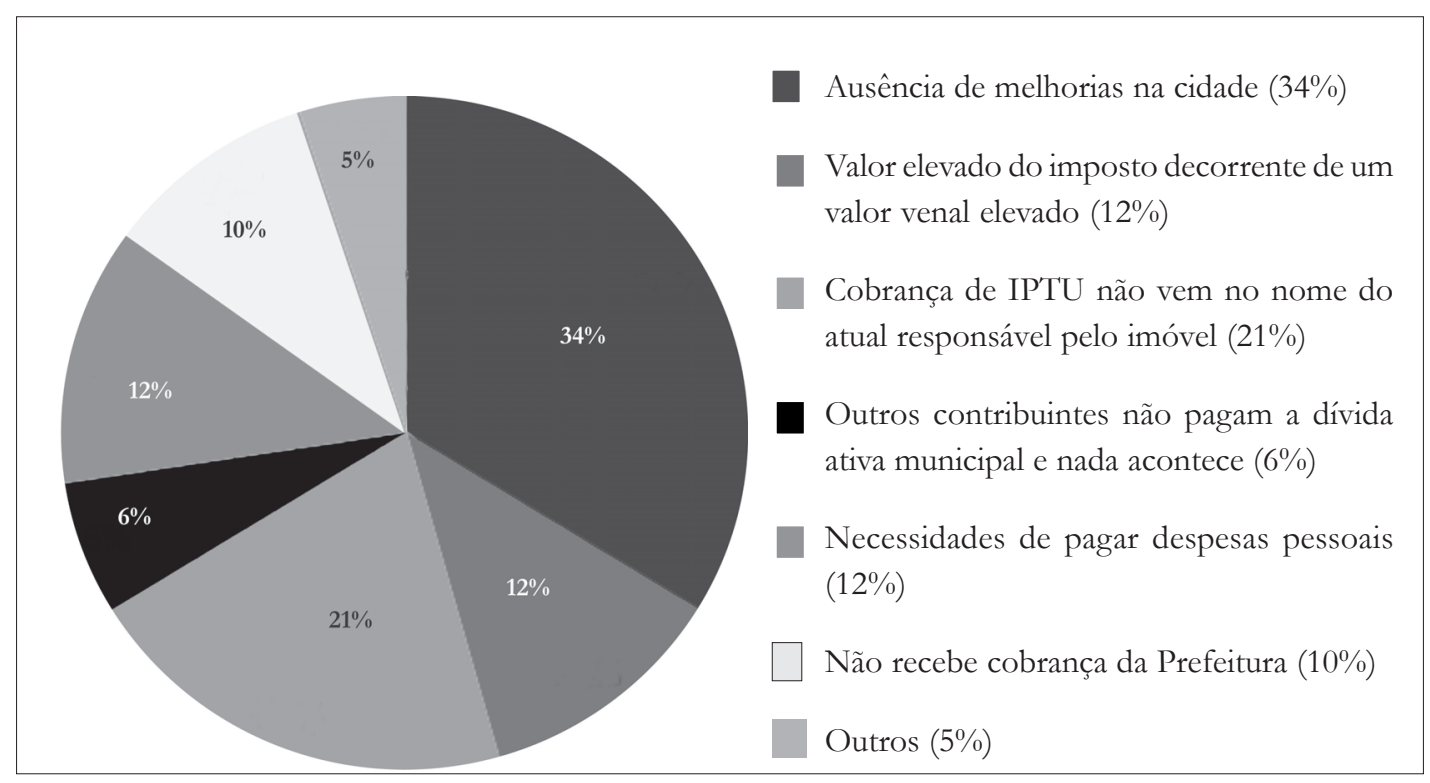

Fonte: $\mathrm{O}$ autor, 2013.

Gráfico 7: Principais motivos que ocasionaram o atraso ou o não pagamento das obrigações tributárias e não tributárias

Outro entendimento que se pode extrair das repostas acima apresentadas pelos munícipes é que o primeiro contato que recebem, em decorrência da pendência com a Fazenda Pública municipal, ocorre por meio do Poder Judiciário, normalmente, por Oficial de Justiça.

Ainda dos 155 respondentes, 81,30\% informaram acreditar que se houvesse alguma visita municipal, a dívida com a Prefeitura teria sido melhor resolvida. Dos devedores, 14,83\% afirmaram que, no período em que estiveram em atraso, receberam carta da Procuradoria de seu Município - Seropédica e Rio de Janeiro - com a finalidade de se resolver o débito por meio da cobrança amigável.

Em relação à possibilidade de a cobrança da dívida ativa acarretar, na esfera judicial, penhora dos bens dos devedores, inclusive do único imóvel residêncial, $88,40 \%$ dos entrevistados informaram desconhecer essa possibilidade.

\section{Pesquisa realizada junto aos servi- dores do TJ/RJ que atuam diretamente sobre a cobrança da dívida ativa}

Para os Oficiais de Justiça foram encaminhados 361 questionários, sendo que 54 afirmaram atuar na cobrança da dívida ativa, contribuindo para a presente pesquisa.

Como ensina Cortella ${ }^{16}$ (2008), a melhor saída para solução de problemas de uma empresa é recorrer, inicialmente, ao "estoque de conhecimento", que se encontra exatamente nos servidores/funcionários que atuam diretamente com a produção.

Ao pesquisar junto aos Oficiais de Justiça do TJ/RJ, que são os servidores do Judiciário que atuam diretamente na cobrança judicial da dívida ativa, e a quem compete, conforme Lopes (2009, p. 211), "medidas das mais importantes em executivos fiscais, como citação, arresto, penhora e avaliação de bens, registro da constrição e intimações em geral, cuja procrastinação 
acabaria por pulverizar a celeridade pretendida na cobrança do crédito público", o presente estudo identificou como as informações mais relevantes as seguintes.

Quanto à realização de cursos de aperfeiçoamento e capacitação oferecidos pelo próprio TJ/RJ por meio da Escola de Administração Judiciária (Esaj), apenas 5,55\% dos entrevistados relatam já ter realizado algum curso voltado para a área de execução fiscal, sendo que não souberam informar qual foi o último ano em que realizaram o curso, bem como qual o ano que o TJ/RJ o disponibilizou pela última vez.

$\mathrm{E}$ a informação que mais chama a atenção, na presente pesquisa, está relacionada aos cursos oferecidos pelo TJ/RJ aos Oficiais de Justiça. Verifica-se, pelos resultados, que os cursos disponibilizados pelo TJ/RJ em sua maioria são para a área cível, com 41 respostas; seguidos pelos de relação de consumo, 28; criminais, com 25; família, 17; Juizados Especiais, com 19 respostas; Outras Áreas, com 18; e, em último, com apenas 3, o de execução fiscal.

Tal realidade revela-se um paradoxo, pois as informações veiculadas pelo próprio $\mathrm{TJ} / \mathrm{RJ}^{17}$ são de que cerca de $56 \%$ de todo o seu acervo cartorário é composto por processos de cobrança do crédito público, mas entre os cursos que oferecem aos Oficiais de Justiça (servidores que atuam de forma direta junto aos contribuintes que se encontram em débito com a Fazenda Pública), o que se encontra em último lugar é exatamente o de execução fiscal.

Uma explicação para esse contrassenso seria a adoção, ainda, de uma administração burocrática (inexistência de cogestão) por parte desse órgão, o que reforça o resultado do estudo do IPEA, que aponta a cultura organizacional burocrática e formalista do Judiciário, associada a um modelo de gerenciamento processual ultrapassado, como a responsável pelo executivo fiscal ser um procedimento moroso e propenso à prescrição.

Faz-se necessário, dessa maneira, que o Poder Judiciário quebre antigos paradigmas históricos herdados de uma administração burocrática, em que os operários/ servidores eram vistos apenas como parte da engrenagem, pois hoje, conforme ensina a literatura, só se alcança os objetivos da qualidade e produtividade por meio de discussões e troca de experiências entre os funcionários que atuam no "chão de fábrica" - servidores (aqueles que trabalham diretamente com a produção) e a alta direção/ magistrados. Ignorar isso, na atual conjuntura, é sinônimo de perda de eficiência.

Outro aspecto relevante apontado na pesquisa, se refere a como deve proceder $\mathrm{o}$ Oficial de Justiça, em caso de verificar, no cumprimento de diligência de citação, que o atual responsável do imóvel não é o citando.

As respostas apontaram que cerca de $7,5 \%$ afirmaram que citam o atual responsável; outros 7,5\% também alegaram que levantam dúvidas e devolvem o mandado sem a citação; $61,11 \%$, que devolvem o mandado sem proceder à citação, mas que identificam o atual responsável, informando seu nome na certidão; Outros $22,22 \%$ que devolvem o mandado sem proceder à citação, mas qualificando o atual responsável, informando na certidão, além do nome, o seu número de RG, CPF e há quanto tempo reside no imóvel. Por fim, um respondente relatou adotar outro procedimento, não especificado.

Dessas respostas podem-se extrair duas informações relevantes: a primeira indica que os diferentes comportamentos adotados pelos Oficiais de Justiça, quando verificam que o citando não é o atual responsável pelo imóvel, realçam a necessidade de padronização de atitudes. Essa 
padronização deveria ser obtida pelo TJ/RJ por meio de cursos da Esaj, voltados exclusivamente para a execução fiscal, os quais, conforme já discutido nesta pesquisa, são praticamente inexistentes.

A segunda informação se refere ao fato de que $83,33 \%$ dos respondentes realizam a identificação do atual responsável do imóvel, ou seja, realizam exatamente o recadastramento imobiliário, que caberia à Prefeitura Municipal, e não ao Poder Judiciário.

Portanto, é mais uma obrigação da Prefeitura Municipal (como a cobrança da dívida ativa, que deveria ter sido realizada em nível administrativo) que é, simplesmente, transferida ao Poder Judiciário.

\section{Pesquisa realizada junto às Prefeituras}

A presente seção analisa os resultados das pesquisas que foram realizadas em Prefeituras fluminenses, com o intuito de visualizar a estrutura referente à cobrança da dívida ativa disponibilizada pelos entes municipais.

No que tange às Prefeituras, o presente estudo abrangeu seis entes municipais, sendo três na Região Metropolitana, dois na Região da Costa Verde e um na Região do Médio Paraíba, e apresentou como principais aspectos os seguintes.

A informação que apresentou maior destaque na presente pesquisa tem relação com a iniciativa do contribuinte devedor em procurar a Prefeitura Municipal, quando provocado juridicamente, para resolver sua pendência fiscal. Numa escala de 1 a 7 (onde 1 é igual a nunca, e 7 é igual a sempre), 50\% dos entrevistados informaram que quase sempre, " 6 ", 0 inadimplente procura a Prefeitura quando provocado pelo Judiciário. Outros 50\% dos respondentes relataram, ao escolher a resposta "4", que os devedores normalmente comparecem.

Outra informação de realce se refere ao prazo médio em que as Prefeituras realizam cadastro imobiliário, uma vez que se pode verificar que $66,67 \%$ dos entes entrevistados afirmaram não realizar esse serviço. A realização a cada dois anos foi respondida por $16,67 \%$ das respondentes, e, a cada três anos, também por $16,67 \%$ das Prefeituras.

Portanto, mesmo com a imperiosa necessidade de os entes públicos manterem cadastro imobiliário atualizado - pois, caso o sujeito passivo cadastrado não seja o correto, a inscrição da certidão da dívida ativa e o seu consequente processo de cobrança serão declarados nulos, jogandose por terra todo o dispendioso trabalho em realizar tais atividades - apenas 33,33\% dos respondentes alegaram realizar esse serviço.

A pesquisa apontou ainda que $50 \%$ dos entes entrevistados afirmaram oferecer biblioteca tributária, bem como treinamento especificamente sobre execução fiscal aos servidores que atuam na cobrança da dívida ativa.

Verifica-se, também, que 50\% dos respondentes afirmaram não existir alguma lei municipal que estimule os contribuintes a pagar suas obrigações tributárias, como o desconto progressivo.

Pelo exposto, com base nos aspectos mais relevantes da presente pesquisa, percebe-se que, quando o contribuinte inadimplente é provocado para honrar suas obrigações junto à Fazenda Pública, o mesmo tem o comportamento de se dirigir à Prefeitura com essa finalidade. Incluindose dados da pesquisa realizada junto à sociedade, em que todos os inadimplentes relataram nunca terem recebido visitas de servidores municipais para iniciar a cobrança 
administrativa, percebe-se, desse modo, que o primeiro contato dos inadimplentes com o Poder Público, no que se refere à cobrança da dívida ativa, ocorre apenas em nível judicial.

\section{Conclusão}

Realizou-se abordagem sobre a dívida ativa, por meio da qual se pretendeu evidenciar a importância do controle de gestão sobre a arrecadação de receitas públicas, no propósito de se aumentar a arrecadação de recursos públicos, tanto na esfera administrativa como na judicial, e, consequentemente, diminuir a quantidade de ações de execução fiscal. O objetivo da pesquisa presume-se alcançado, sendo que algumas considerações serão a seguir apresentadas.

Ao incluir o Poder Judiciário na discussão que se refere ao aperfeiçoamento do controle de gestão sobre a dívida ativa, por essa instância ter intensa relação com a arrecadação de recursos públicos para a administração pública brasileira, por meio da execução fiscal, a presente pesquisa evidenciou que o Judiciário, no que tange a suas características gerenciais, ainda se encontra abraçado com o modelo de administração burocrático, considerado inadequado para o contexto institucional contemporâneo, por sua ineficiência, morosidade, inexistência de cogestão, resistência às mudanças, privilégio do cumprimento de tarefas em detrimento da obtenção dos resultados, excesso de formalismo, dificuldades no atendimento a clientes/cidadãos e, ainda, por não ser voltado para o controle da receita pública.

A presente pesquisa sugere, como procedimentos a serem utilizados pelo Judiciário, abandonar as características da administração burocrática responsáveis por sua ineficiência e adotar a administração gerencial, com o intuito de melhorar a arrecadação da dívida ativa na execução fiscal.

Quanto à aplicabilidade do controle judicial, para uma maior efetividade na gestão da dívida ativa, a Lei de Improbidade Administrativa, considerada, por alguns estudiosos, como o maior instrumento legislativo da República Brasileira, é uma importante ferramenta a ser aplicada sobre os atos dos agentes públicos Secretários Municipais, Prefeitos e servidores do próprio Judiciário - que causem perdas patrimoniais aos Municípios, na gestão da dívida ativa. Tal lei deve também ser aplicada aos que deixarem de aplicá-la, pois não apurar improbidade administrativa é improbidade.

Desse modo, como forma de estimular, de forma imediata, os agentes públicos a realizarem a cobrança administrativa da dívida ativa com parâmetros mais próximos das regras da boa administração, aumentando, assim, o recebimento dessa receita pública, com a consequente diminuição de seu estoque patrimonial, e, inclusive, com a diminuição de novas ações de execução fiscal, sugere-se que o Judiciário, em parceria do MP/RJ e do TCE/RJ, deixe de tratar a Lei de Improbidade Administrativa como um desafio ou como a "Ação do Futuro", e faça essa lei produzir os efeitos que a sociedade brasileira precisa.

No que se refere ao Poder Executivo Municipal, a presente pesquisa sugere a criação de lei de âmbito nacional que determine a criação de órgãos municipais para trabalharem exclusivamente com o controle da receita pública, em especial, com a cobrança da dívida ativa, contribuindo, desse modo, não apenas para uma melhor gestão sobre a arrecadação municipal, mas também, para a mudança cultural da 
administração pública brasileira, que muita ênfase despende ao controle da despesa pública, criando órgãos para esse fim (CGU, TCU, Tribunais de Contas Estaduais e, inclusive, Tribunais de Contas Municipais), e pouco se volta à gestão da receita pública. Esse órgão municipal funcionaria, inclusive, como um mecanismo prévio na área administrativa, que impediria que as cobranças de dívida ativa fossem encaminhadas diretamente à Justiça, contribuindo, dessa maneira, para aliviar o Poder Judiciário.

A nova legislação elencaria outros deveres às Prefeituras Municipais, não as limitando apenas aos requisitos da CDA, previstos na Lei $\mathrm{n}^{\circ} 6.830 / 80$, para poderem recorrer ao Judiciário, fazendo-as comprovar, assim, que de fato foram esgotadas todas as oportunidades para a quitação dos débitos fiscais a nível administrativo. Seguem algumas sugestões:

- expedição de certidão no local do imóvel, no caso de cobrança do IPTU, por servidor pertencente ao órgão municipal, informando a qualificação do responsável pelo bem objeto da dívida;
- envio dos nomes de devedores inscritos em dívida ativa aos cartórios de protestos;

- menores prazos para iniciar a cobrança administrativa e judicial;

- realização periódica do cadastro imobiliário.

Em relação às atribuições, tal órgão municipal, por tratar exclusivamente da receita pública, possuiria maior disponibilidade para melhor administrar as receitas da competência municipal, em especial as tributárias, o que contribuiria para diminuir a dependência desses entes das transferências de recursos da União e dos Estados.

Concluindo a presente pesquisa, que não teve por finalidade esgotar o tema, sugere-se a realização de outros trabalhos que, como este, contribuam para aperfeiçoar o controle da receita pública, especialmente sobre a dívida ativa, com o propósito de se preencher a lacuna existente, devido à escassez de pesquisas na literatura científica sobre esse assunto.

(Artigo recebido em dezembro de 2012. Versão final em dezembro de 2013).

\section{Notas}

${ }^{1}$ Municípios ausentes à análise, por não constarem no FINBRA de 2009, eis que não encaminharam suas contas referentes ao exercício fiscal à STN, a despeito do art. 51 da LRF: Arraial do Cabo, Carapebus e Paraíba do Sul.

${ }^{2}$ Municípios ausentes à análise, por não constarem no FINBRA de 2010, eis que não encaminharam suas contas referentes ao exercício fiscal à STN, a despeito do art. 51 da LRF: Arraial do Cabo e Duas Barras.

${ }^{3}$ Finanças do Brasil (FINBRA) - Banco de dados consolidado pela STN com informações orçamentárias declaradas pelos próprios Municípios. São dados oficiais referentes a despesas, receitas, ativos e passivos dos entes públicos municipais.

${ }^{4}$ Municípios ausentes à análise, por não constarem no FINBRA de 2010, eis que não encaminharam suas contas referentes ao exercício fiscal à STN, a despeito do art. 51 da LRF: Arraial do Cabo e Duas Barras. 
${ }^{5}$ Finanças do Brasil (FINBRA) - Banco de dados consolidado pela STN com informações orçamentárias declaradas pelos próprios Municípios. São dados oficiais referentes a despesas, receitas, ativos e passivos dos entes públicos municipais.

${ }^{6}$ Despesas de investimentos são, conforme Carvalho Filho (2010, p. 351), “as despesas com o planejamento e a execução de obras, inclusive com a aquisição de imóveis considerados necessários à realização destas últimas, e com a aquisição de instalações, equipamentos e material permanente". Escolas, creches e hospitais bem equipados, ruas pavimentadas, iluminação pública, acesso ao lazer, transporte eficiente, são exemplos de investimentos municipais capazes de promover a cidadania e o bem-estar da população.

${ }^{7}$ Debate "O Aprimoramento das Ferramentas da Cobrança da Dívida Ativa" - Auditório da Escola da Magistratura do Rio (Emerj), ocorrido no dia 8 de agosto de 2012.

${ }^{8}$ Certidão da Dívida Ativa.

${ }^{9}$ Controle judiciário ou judicial é aquele exercido exclusivamente pelos órgãos do Poder Judiciário, sobre os atos administrativos do Poder Executivo, do Legislativo e do próprio Judiciário quando este realiza atividades administrativas.

${ }^{10}$ Seminário Improbidade Administrativa - Auditório da Escola da Magistratura do Rio (Emerj), ocorrido no dia 15 de agosto de 2012.

${ }^{11}$ IBGE/ 2010 - Disponível em <http://www.ibge.gov.br/home/presidencia/noticias/ noticia_visualiza .php ?id_noticia $=1766>$. Acesso em 6. jul. 2012.

${ }^{12}$ META3 -disponível em: < http:/ / www.cnj.jus.br/noticias/9060-meta-3-preve-a-reducaode-20dos-processos-de-execucao-fiscal>. acesso em 12 jun. 2012.

${ }^{13}$ Execução fiscal é o processo de cobrança da dívida ativa, realizado por meio do Poder Judiciário, no qual a administração pública exige do sujeito passivo devedor aquilo que lhe é devido e não foi pago na época própria.

${ }^{14}$ No Tribunal de Justiça do Rio de Janeiro, 56\% de todo seu acervo cartorário é composto de ações dessa natureza; cobrança de tributos vencidos.

${ }^{15}$ Custo Unitário do Processo de Execução Fiscal na Justiça Federal. Disponível em: <http:// www.ipea.gov.br/portal/index.php?option=com_content\&view $=$ article\&id=7872>. Acesso em: 17 jul. 2012.

${ }^{16}$ Mario Sérgio Cortella - Palestra ocorrida em 2008, disponível em: http://www. quintalvirtual.blog.br /?p=927. Acesso em 26 jul. 2012.

${ }^{17}$ Presidente do TJ reúne prefeitos para tentar diminuir acervo de executivos fiscais - disponível em: <http://portaltj.tjri.jus.br/web/guest/home/-/noticias/visualizar/75404>. acesso em 12 out. 2012 .

\section{Referências bibliográficas}

Alexandrino, Marcelo; Vicente, Paulo. Direito Administrativo Descomplicado. $18^{a}$ Ed. São Paulo: Método, 2010.

Almeida, Edvaldo Nilo. Direito Tributário - Tomo I - 2a ed., Salvador: Editora JusPodivm, 2012. 
Barros, Guilherme Freire de Melo. Poder Público em Juizo para Concursos. Salvador: Editora JusPodivm, 2011.

Barroso, Luiz Felizardo. A Resolução 33 do Senado e a Dívida Ativa. Valor Econômico, São Paulo, 02 out. 2006. Disponível em:<http://www.valoronline.com.br1>. Acesso em: 11 nov. 2012.

Borba, Claudio. Direito Tributário. 13. ed. Rio de Janeiro: Editora Impetus, 2003.

Brasil. Lei $\mathrm{n}^{2}$ 5.172, de 25 de outubro de 1966. Dispõe sobre o Sistema Tributário Nacional e institui normas gerais de direito tributário aplicáveis à União, Estados e Municípios. Diário Oficial da União, 31 de outubro de 1966 (retificado).

Lei no 4.320, de 17 de março de 1964. Estatui normas gerais de Direito Financeiro para elaboração e controle dos orçamentos e balanços da União, dos Estados, dos Municípios e do Distrito Federal. Diário Oficial da União, 23 de março de 1964, retificado em 9.4.1964 e retificado em 3.6.1964.

. Lei $\mathrm{n}^{\mathrm{O}} 6.830$, de 22 de setembro de 1980. Dispõe sobre a cobrança judicial da Dívida Ativa da Fazenda Pública, e dá outras providências. Diário Oficial da União, 24 de setembro de 1980 .

. Lei no 8.009 , de 29 de março de 1990. Dispõe sobre a impenhorabilidade do bem de família. Diário Oficial da União, 30 de março de 1990.

Lei n⿳⺈ 8.429, de 2 de junho de 1992. Dispõe sobre as sanções aplicáveis aos agentes públicos nos casos de enriquecimento ilícito no exercício de mandato, cargo, emprego ou função na administração pública direta, indireta ou fundacional e dá outras providências. Diário Oficial da União, 3 de junho de 1992.

. Lei Complementar $\mathrm{n}^{2} 118$, de 9 de fevereiro de 2005. Altera e acrescenta dispositivos à Lei n 5.172, de 25 de outubro de 1966 - Código Tributário Nacional, e dispõe sobre a interpretação do inciso I do art. 168 da mesma Lei. Diário Oficial da União, 09 de fevereiro de 2005.

Portaria PGFN no 321, de 06 de abril de 2006. Dispõe sobre o protesto de Certidão de Dívida Ativa da União. Diário Oficial da União, 06 de abril de 2006.

. Lei no 5.351 , de 15 de dezembro de 2008. Dispõe sobre medidas para a incremento da cobrança de créditos inscritos em Dívida Ativa do Estado do Rio de Janeiro, altera a Lei $\mathrm{n}^{-}$1.582, de 04 de dezembro de 1989, e dá outras providências. Diário Oficial da União, 15 de dezembro de 2008.

Bresser-Pereira, Luiz Carlos. Da administração burocrática à gerencial. Revista do Serviço Público, Brasília, 1996.

Carvalho Filho, José dos Santos. Manual de Direito Administrativo. 23ae ed. Rio de Janeiro: Editora Lumen Juris, 2010.

Di Pietro, Maria Sylvia Zanella. Direito Administrativo. 19ªe ed. São Paulo: Atlas, 2006.

FerreIra, Pedro Cavalcanti. Investimento em Infra-Estrutura no Brasil: fatos estilizados e relações de longo prazo. Revista Pesquisa e Planejamento Econômico, v. 26, n. 2, agosto 1996. Kohama, Heilio. Contabilidade Pública: teoria e prática. 10ª ed. São Paulo: Atlas, 2006. Lopes, Mauro Luis da Rocha. Direito Tributário Brasileiro. 1. ed. Niterói: Impetus, 2009. MERTOn, Robert K. Social theory and social structure; toward the codification of theory and research. Glencoe: Free Press, 1949. 
Neves, Marcus Alonso Ribeiro; Pinto, Marcos Roberto. A importância da Dívida Ativa no gerenciamento e no equilíbrio das contas do município. Revista de Administração Municipal, Rio de Janeiro, no 2587 a 16, abril de 2006.

Rio de Janeiro. Lei no 5351, de 15 de dezembro de 2008. Dispõe sobre medidas para incremento da cobrança de créditos inscritos em dívida ativa do estado do Rio de Janeiro, altera a Lei no 1.582 de 04 de dezembro de 1989, e dá outras providências. Diário Oficial do Rio de Janeiro, 16 de dezembro de 2008.

Tristão, José Américo Martelli. A administração tributária dos municípios brasileiros: uma avaliação do desempenho da arrecadação. Tese (doutorado em Administração). Fundação Getúlio Vargas, São Paulo, 2003. 


\section{Resumo - Resumen - Abstract}

\section{Dívida Ativa: análise da cobrança administrativa e judicial em Municípios do Rio de Janeiro \\ Marcello Sartore de Oliveira e Waldir Jorge Ladeira dos Santos}

Este estudo tem como objetivo contribuir para o aperfeiçoamento do controle sobre a dívida ativa. A metodologia utilizada recaiu sobre pesquisas bibliográficas, documental e de campo, envolvendo Municípios do Rio de Janeiro. Os dados analisados demonstram que a ausência de leis mais rígidas na cobrança desses créditos, a impunidade, as falhas do Judiciário, por ainda adotar o modelo burocrático de administração, e, especialmente, os fatores políticos, servem de justificativa para se apontar a necessidade de estudos sobre esse tema. Por fim, pode-se concluir que deve o Judiciário utilizar-se da Lei de Improbidade Administrativa e eliminar as disfunções da burocracia, como forma de aumentar a eficiência na cobrança dessa receita. Quanto aos Municípios, sugere-se instituição de lei que determine a criação de órgãos que trabalhem exclusivamente com a receita pública, em especial com a cobrança da dívida ativa, contribuindo para a mudança cultural da administração pública brasileira, que muita ênfase despende ao controle da despesa e pouco se volta à gestão da receita pública.

Palavras-chave: dívida ativa; prefeituras; judiciário; controle

\section{Deuda Activa: análisis del cobro administrativo y judicial en municipios del Río de Janeiro \\ Marcello Sartore de Olivo y Waldir Jorge Ladeira de Santos}

Este estudio tiene como objetivo contribuir para la mejora del control sobre la deuda activa. La metodología utilizada fue la investigación bibliográfica, documental y estudio de campo, en municipios del Río de Janeiro. Los datos analizados demuestran que la ausencia de leyes más rígidas en el cobro de esos créditos, la impunidad, los errores judiciales, por aún adoptar el modelo burocrático de administración, y, especialmente, los factores políticos, sirven de justificación para señalar la necesidad de estudios sobre este tema. Por fin, se puede concluir que debe el Poder Judicial utilizarse de la Ley de Improbidad Administrativa y eliminar las disfunciones de la burocracia, como una medida para aumentar la eficiencia en el cobro de los ingresos. En cuanto a los municipios, se sugiere establecimiento de ley que determine la creación de órganos que trabajen exclusivamente con los ingresos públicos, en especial con el cobro de la deuda activa, contribuyendo para el cambio cultural de la administración pública brasileña, que mucha énfasis desprende al control del gasto y poco se vuelve a la gestión de los ingresos públicos.

Palabras clave: deuda activa; ayuntamientos; poder judicial; control

\section{Active debt: an analysis of the administrative and judicial collection in Rio de Janei- ro municipalities}

\section{Marcello Sartore de Oliveira and Waldir Jorge Ladeira dos Santos}

This paper aims to contribute for the improvement of the active public debt control, by using bibliographic, documental, and field research on Rio de Janeiro municipalities. The data show that the lack of strict laws for credit collection, impunity, flaws from the Judiciary, the adoption of a bureaucratic model of management, and especially political factors justify the importance of studies on this subject. One important conclusion from this paper is that the Judiciary must make use of the Administrative Improbity Law and eliminate bureaucratic 
disfunctions, in order to improve the efficiency of credit collection. Regarding municipalities, we suggest the institution of a law to force the creation of departments exclusively dedicated to revenue, especially on the collection of the active debt, thereby contributing for a cultural change in the Brazilian public administration, which is mainly focused on public spending control.

Keywords: public debt; municipalities; Judiciary; control

Marcello Sartore de Oliveira é mestre em Ciências Contábeis pela Universidade Estadual do Rio de Janeiro (UERJ) e atua como professor de Contabilidade Empresarial na Universidade Candido Mendes (UCAM). Contato: msartoliveira@gmail.com

Waldir Jorge Ladeira dos Santos é doutor em Política Pública e Formação Humana pela Universidade Estadual do Rio de Janeiro (UERJ) e professor adjunto do Programa de Mestrado em Ciências Contábeis da UERJ. Contato: wcladeira@uol.com.br 